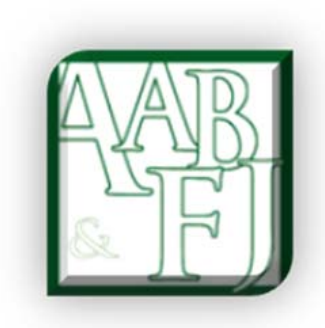

\title{
The Relationship between Foreign Direct Investment from Thailand and Export on the Economic Growth of Laos
}

\author{
Thanet Wattanakul ${ }^{1}$ and Tanawat Watchalaanun ${ }^{2}$
}

\begin{abstract}
This study examines the relationship between Laos's GDP, Thailand's direct investment to Laos and Laos's export to Thailand by using 44 quarters of data from 2005 Q1 to 2015 Q4. All relationships were studied using the vector error correction model (VECM). The results presented long run relationship from Laos' GDP and Laos' export to Thailand as well as from Thailand's direct investment to Laos's GDP and Laos's export to Thailand. In the short run, there was only unidirectional relationship from Laos's GDP to Laos's exports to Thailand. This study indicates that Laos's exporters receive benefits from Thailand's direct investment contribution to accelerate economic growth in the short term. Therefore, Laos's government should distribute income from the exporters to other economy sectors or spread the types of export goods into a larger range.
\end{abstract}

JEL Classification: F63, F40, O53

Keywords: FDI, Export, Economic Growth, VECM, vector error correction model

\footnotetext{
${ }^{1}$ Khon Kaen University, Nong Khai Campus, Thailand

${ }^{2}$ Khon Kaen University, Nong Khai Campus, Thailand
} 


\section{Introduction}

In the last century, foreign direct investment (FDI) was an important mechanism for driving the global economy. In general, the capital flow effect on production in host countries was achieved by eliminating the investment gap in those countries, especially in developing countries which have low investment levels, and the benefit was returned to the foreign investors' home countries via higher revenue or lower cost. Dunning (2001) presented three advantages which provided motivation for the flow of capital from home countries into host countries. One was the location advantage, where the investor would benefit from the specific host countries' national resources, labor skills, lower rent or wages, host country economy etc. The second advantage was the ownership advantage which provided benefits for foreign investors through ownership of special equipment or proficiency in production. This meant that they were able to produce more efficiently than other firms. The last advantage which Dunning noted was the internalization advantage. This benefitted investors by providing privileges which were given by the host country government or the other organisations which aimed to galvanise investment in the host country. However, Asiedu (2002) found the difference between the effect of return on a group of countries and the given situation to have an adverse regional effect.

There are some studies which confirm the effect of FDI on gross domestic product (GDP) such as Balasubramyam, Salisu and Sapsford (1996) who found there was a positive effect of FDI in 46 countries on GDP and more effect of FDI to GDP in countries which use export promoting strategies than in countries which use import substituting strategies. Borensztein, Gregorio and Lee (1998) found the effect of FDI on growth was dependent on the level of human capital available in the host economy. Tekin, R, B. (2012) studied the causality relations among real GDP, real exports and real net FDI inflows among least developed countries and found Granger causality from FDI to GDP in Bernin and Togo and GDP to FDI in Burkin Faso, Gambia, Madagascar and Malawi. Moreover, there was evidence of export Granger-causing GDP in Haiti, Rwanda and Sierra Leone and GDP Granger-causing export in Angola, Chad and Zambia. While studying the export and FDI relations indicated that there was the causality from FDI to export in Bennin, Chad, Haiti, Mauritania, Niger, Togo, and Yemen and from exports to FDI in Haiti, Madagascar, Mauritania, Malawi, Rwanda, Senegal and Zambia. Carkovic and Levine (2002) argued the stability of this effect. This study estimated the effects of FDI inflows on economic growth in many conditions and it was found that there was significantly effect of FDI on GDP when estimated with panel data but not significantly using cross section data. The impact of FDI on growth which depends on other factors such as the stock of human capital, financial and trading showed the same problem.

The Lao People's Democratic Republic is a developing country in Greater Mekong Sub-region (GMS) in South-East Asia. The economy is such that there is only low incomes and a substantial saving problem showing over the long term. However, there is an abundance of natural resources such as minerals, forests, and water. The effect of low incomes and low savings meant that there were only limited financial resources to develop industries, while the wealth of natural resources were attractive investments but domestic investors were potentiality insufficient. Thus, foreign direct investment was necessary for Lao PDR development. 
Freeman (2002) examined the foreign direct investment situation in Cambodia, Laos and Vietnam. It is shown that the majority foreign investor within this region during the colonisation period was France. The investment increased the economy activity in many sectors such as the mining sector, agricultural sector, industrial activities, and investment and financing of the colonial country. After the colony era, Laos had important political changes especially including the regime. The early policy of the new governor was to deny foreign investment. Laos is opening up again as a country in this region, which includes Cambodia, Vietnam. They have had to learn how to attract, retain, sustain, manage, harness, and monitor the FDI inflows for developing their country after the foreign investment pause in the prior period. Gunanwardana and Sisombat (2008) studied the trends and patterns of foreign direct investment in Lao PDR since the promulgation of FDI law in 1988. The paper focus is on inflows of FDI to Laos during 1988 to 2004. At the beginning, foreign investment was very small. Until the early 1990s there was only a gradually increase and then rapidly rose during the period from 1998 to 2004. The largest source of investment during this period was ASEAN investors. The top four investors in all business sectors in 2003 were China, South Korea, Malaysia and Thailand. However, investment in the period from 1989 to 2015 in Laos showed that the largest investment was in the electricity generation sector, the second was mining, and the third was agriculture (Laos's Ministry of Planning and Investment, 2016). The majority foreign investor was China, the second was Thailand and the third was Vietnam. The total domestic investment in Laos from 1989 to 2015 was about 25 percent while foreign investment was about 75 percent. (See appendix 1). It indicated that the Laos investment sector was unavoidably dependent on the foreign section.

One of the most important investment sources in Laos was Thailand. There were many similarities between the two countries especially the common language which other countries in the region did not share, there was also a common history, culture, and religious beliefs. Additionally, the membership of Association of South East Asia Nations (ASEAN) of both countries supported the capital flow and trading among the group.

The total foreign investment from Thailand into Laos since 1989 to 2015 was about 748 projects or 4,491 million US\$ or about 18.35 percent (Ministry of Planning and Investment in 2016). Bank of Thailand (2016) presented the information of Thailand direct investment in Laos (FDI inflow) and Thailand import from Laos (Laos export to Thailand) since 2005 to 2015. of the flow of capital shows that there was a significant increase in the direct investment from Thailand into Laos from 2005 to 2013, slightly decreased in 2014 and rose again in 2015. Meanwhile, at the same time there was an increasing trend of Laos exports into Thailand. Since 2005 to 2011, Laos export into Thailand was slightly fluctuated before gradual rising from 2012 to 2015 (appendix 2 ). The situation can be observed via the relationship in both variables. Therefore, there probably is an advantage for the government to decide to support a foreign investment policy if the relationship can be proved.

Therefore, this study aims to examine the relationship between Laos's GDP, Thailand direct investment in Laos and Laos exports into Thailand by using vector error correction mechanism (VECM) and granger causality methods. The methodology is presented in the next section followed by the empirical results. Conclusion and discussion is presented in the final section. 


\section{Methodology}

This study proposes to prove the relationship among 3 variables, Laos's GDP, Thailands' direct investment in Laos and Lao's exports to Thailand. The data was collected from 2 sources, Laos's GDP was collected from UNCTAD statistic given as GDP, Thailand direct investment in Laos which (given as FDI) and Laos export to Thailand (given as Export) were collected from Bank of Thailand. The capital inflow and trading variables were collected as quarterly data from 2005 Q1 to 2015 Q4 while GDP was collected as annual data from 2005 to 2015 before interpolated by Chow-Lin method into quarterly data from 2005 Q1 to 2015 Q4.Therefore, there were 44 observation in this estimation. All variable measures are in US dollars at current prices in millions and transformed into logarithm form. This section explained the four stages which were applied to test unit root, co-integration, error correction mechanism and granger causality test.

\section{1) Stationary Test}

Almost all macroeconomic time series variables were non-stationary, they had no tendency to return to long-run deterministic path and the variance was time dependent (Nelson and Plosser, 1982). There are provided using the non-stationary variable in the regression by ordinary least square (OLS), there was spurious regression and unbelievable results. The normally method for investigating non-stationary property was Augment Dickey Fuller (ADF-test) and Phillips Pearson (PP-test). Both approaches had the same model but different estimating processes by using the t-test statistic. This process also examined the stationary property by using the following equations.

$$
\begin{aligned}
& \Delta X_{t}=\alpha X_{t-1}+\sum_{i=1}^{p} \omega_{i} \Delta X_{t-i}+\varepsilon_{t} \\
& \Delta X_{t}=\delta+\alpha X_{t-1}+\sum_{i=1}^{p} \omega_{i} \Delta X_{t-i}+\varepsilon_{t} \\
& \Delta X_{t}=\delta+\gamma \theta+\alpha X_{t-1}+\sum_{i=1}^{p} \omega_{i} \Delta X_{t-i}+\varepsilon_{t}
\end{aligned}
$$

Where $X$ was examined variable, $\mathrm{t}$ was any time, ${ }^{\varepsilon_{t}}$ was error term, $\alpha$ was $\mathrm{X}$ coefficient, $\delta$ was intercept term, $\gamma \theta$ was trending term and $\sum_{i=1}^{p} \omega_{i} \Delta X_{t-i}$ autoregressive process term. Eq (1) was model which estimated without intercept and trending in process, while Eq (2) was estimated with intercept in process and Eq (3) was estimated with intercept and trending in process. However, all equations above which approach by PP-test were none term of autoregressive

process.

The stationary property considered by $\alpha$. If $\alpha$ was equal $0, \mathrm{X}$ was non-stationary while $\mathrm{X}$ was stationary if $\alpha$ less than 0 . For tested the condition, Coefficient $(\alpha)$ would transform into ADF$\mathrm{t}$ statistic by following.

$$
A D F=\frac{\hat{\alpha}}{S E(\hat{\alpha})}
$$


ADF-t statistic would be compare with McKinnon critical value for conclude stationary potential. If ADF-t statistic is more than McKinnon critical value, the variable will nonstationary. In contrast, the variable will stationary if ADF-t statistic is less than McKinnon critical value.

Explained variables may be non-stationary at level or $\mathrm{I}(0)$. However, they may be stationary at higher order of integrated I(1) or I(2). Therefore, if empirical results at level was unit root, the variable should test again at higher order of integrated. This process was finished when the stationary level of all variables was found at the second differential.

\section{2) Co-integration}

The regression by OLS was not appropriate in cases of estimated variables which were nonstationary. However, they might have a long-run relationship if there are co-integration (Engle and Granger, 1987). Later, Johansen presented the new approach which could estimate many equation base on Vector autoregressive (VAR) process for test co-integration property as the system-based reduced rank regression approach (Johansen Co-integration test). Co-integration test in this study would be use the co-integration testing which present by Johansen (1988) for investigate the long run relationships between FDI, GDP and Export by following:

$$
\left[\begin{array}{c}
\Delta F D I_{t} \\
\Delta G D P_{t} \\
\Delta \text { Export }_{t}
\end{array}\right]=\left[\begin{array}{ccc}
\beta_{0} & \beta_{1} & \beta_{2} \\
\vartheta_{0} & \vartheta_{1} & \vartheta_{2} \\
\kappa_{0} & \kappa_{1} & \kappa_{2}
\end{array}\right]\left[\begin{array}{c}
F D I_{t-1} \\
G D P_{t-1} \\
\text { Export }_{t-1}
\end{array}\right]+\left[\begin{array}{c}
u_{t} \\
v_{t} \\
w_{t}
\end{array}\right]
$$

When $\left[\begin{array}{ccc}\beta_{0} & \beta_{1} & \beta_{2} \\ \vartheta_{0} & \vartheta_{1} & \vartheta_{2} \\ \kappa_{0} & \kappa_{1} & \kappa_{2}\end{array}\right]_{\text {vector was the parameter, }}\left[\begin{array}{c}u_{t} \\ v_{t} \\ w_{t}\end{array}\right]_{\text {was the vector of error term. The approach }}$ was based on the concept that if variables were co-integrated, then the rank of vector of parameter wasn't zero. The statistical which used for proving the hypothesis was $\lambda_{\text {trace and }} \lambda_{\max }$ eigenvalue. Null hypothesis of $\lambda_{\text {trace }}$ eigenvalue was the number of co-integration vector was rank $<\mathrm{k}$ while the alternative that rank $=\mathrm{k}$ and Null hypothesis of $\lambda_{\max }$ eigenvalue was $\operatorname{rank}<\mathrm{k}$ while the alternative hypothesis was rank $=\mathrm{k}+1$.

\section{3) Vector Error Correction Mechanism (VECM)}

Error correction mechanism could show the short-run and long-run relation and the speed of adjustment from explained variable return to the equilibrium after independent variables were changed. The classical Error correction mechanism was improved by numerous statisticians. This process used the approach which can be explain many equation on the model base on VAR process as Vector Error Correction Mechanism. The model could be form as the following:

$$
\left[\begin{array}{c}
\Delta F D I_{t} \\
\Delta G D P_{t} \\
\Delta \text { Export }_{t}
\end{array}\right]=\left[\begin{array}{l}
A_{0} \\
B_{0} \\
C_{0}
\end{array}\right]+\left[\begin{array}{l}
A_{1} \\
B_{1} \\
C_{1}
\end{array}\right] E C_{t-1}+\left[\begin{array}{ccc}
D_{1} & D_{2} & D_{3} \\
E_{1} & E_{2} & E_{3} \\
F_{1} & F_{2} & F_{3}
\end{array}\right]\left[\begin{array}{c}
\Delta F D I_{t-1} \\
\Delta G D P_{t-1} \\
\Delta \text { Export }_{t-1}
\end{array}\right]+\left[\begin{array}{c}
p_{t} \\
q_{t} \\
r_{t}
\end{array}\right]
$$


Where $\left[\begin{array}{c}A_{0} \\ B_{0} \\ C_{0}\end{array}\right]$ was constant matrix, $\left[\begin{array}{l}A_{1} \\ B_{1} \\ C_{1}\end{array}\right]_{\text {was coefficient matrix of error correction }}$ component and presented the speed of adjustment of model, $\left[\begin{array}{c}p_{t} \\ q_{t} \\ r_{t}\end{array}\right]_{\text {was error term in each model }}$ and $E C_{t-1}$ was a vector of error term in the Johansen test. Long-run relation was accepted if the coefficient of vector error correction was negative significantly. This study would present the long-run relationship and speed of adjustment from this approach. The short run effect would present for testing Granger Causality in the next process.

\section{4) Granger Causality test}

This testing was based on the idea that the explanatory variable was Granger causes of explained when the lag of explanatory variable could explain the dependent variable than only lag of themselves (Freeman, 1983). This study used short run effect from the independent variable to dependent variable which showed the effect of the explanatory lag for proving the causality. If the independent variables can explain the dependent variable, all of lag coefficient wasn't significantly as zero. This hypothesis would be proved by Wald test.

\section{Estimation Results and Discussion}

This section presented the empirical result and discussion. The stationary check results were shown in the Table 1. Co-integration test results and Error Correction Mechanism results are presented in Table 2 and Table 3. The table 4 shows the Granger Causality results.

The stationary property test indicated that all variables were stationary at level by PP test but there were 2 variables which stationary at level by ADF-test. However, this difference was acceptable. This results indicated that all variables could estimate the long-run relationship on co-integration testing.

Table 1 Stationary Test Results

\begin{tabular}{|c|c|c|c|c|c|c|}
\hline \multirow[t]{2}{*}{ Variable } & \multicolumn{3}{|c|}{ ADF-test } & \multicolumn{3}{|c|}{ PP-test } \\
\hline & None & Intercept & $\begin{array}{l}\text { Intercept and } \\
\text { trending }\end{array}$ & None & Intercept & $\begin{array}{l}\text { Intercept and } \\
\text { trending }\end{array}$ \\
\hline FDI & 1.6307 & $-4.7185 * * *$ & $-4.3225 * * *$ & 0.0233 & $-3.1514 * *$ & $-5.0455^{* * *}$ \\
\hline GDP & 0.8504 & -2.1558 & 0.4703 & 6.2495 & $-4.0669 * * *$ & -0.0036 \\
\hline Export & 1.2527 & $-2.9369 * *$ & $-4.3604 * * *$ & 1.4491 & $-3.0622 * *$ & $-4.3572 * * *$ \\
\hline
\end{tabular}

Note: Selected by the Schwarz Information Criterion (SC)

*** Significant at 0.01

** Significant at 0.05 
From the co-integration test results in table 2, there were long run relation along the variables. Estimated $\lambda_{\text {trace }}$ and $\lambda_{\max }$ were 0.5081 and significantly at 0.01 and indicated that there are 2 cointegration in the system.

Table 2 Co-integration Results

\begin{tabular}{|c|c|c|c|c|}
\hline \multirow{2}{*}{ Lag } & \multicolumn{2}{|c|}{ Eigen Value } & \multicolumn{2}{c|}{ Number of Co-integration } \\
\cline { 2 - 5 } & Trace & Maximum & Trace & Maximum \\
\hline $\mathbf{3}$ & $0.5081^{* * *}$ & $0.5081^{* * *}$ & 2 & 2 \\
\hline
\end{tabular}

Note: selected by the Schwarz Information Criterion (SC)

**** Significant at 0.01

Vector Error Correction result are presented in table 3. The long-run relationship from GDP and export into FDI was found from FDI and GDP into export by a significant return to equilibrium which is shown by the EC1 coefficient. Even there was two co-integration but the EC2 was weaker. Thus, it can explain that shock pushed the dependent variables out of equilibrium as well as FDI would adjusted to equilibrium faster than export.

Long run relationship from GDP and Export into FDI conform the eclectic paradigm of international production of Dunning (2001). In the long run, Thailand investors are attracted by location advantage which is shown by Laos's GDP and the increase of potential export from Laos into Thailand. If Laos' Government want to increased long term direct investment, they should be allow openness in the trading sector and enlarge the domestic economy.

In the path of long run relationship from FDI and GDP into Export, according the big problem was the inability to increase production while still being rich in natural resources, Thailand capital inflow relieved the issue by increasing the investment in Laos and the ability for natural resources to be utilised to improve Lao's GDP. Both sectors increased the productivity and output which were mostly input from other industries such as wood and mineral in Thailand. In the other word, there was increase input supply for other industries in Thailand. Thus, improving Thailand's direct investment and Lao's GDP effect on Lao's Exports into Thailand.

However, there was not FDI and export effect on GDP in long run. It is probably be that human capital development in Laos wasn't enough to cause an effect on the relationship from FDI to GDP as Borensztein, Gregorio and Lee (1998) indicated the importance of human capital on the long run relationship while Laos's Export into Thailand is exogenous which depends on Thailand demand. 
Table 3 Vector Error Correction Mechanism (VECM) Results

\begin{tabular}{ccccc}
\hline \multirow{2}{*}{$\begin{array}{c}\text { Dependent } \\
\text { Variable }\end{array}$} & \multicolumn{2}{c}{ EC1 } & \multicolumn{2}{c}{ EC2 } \\
\cline { 2 - 5 } & Coefficient & t-statistic & Coefficient & t-statistic \\
\hline FDI & -0.5437 & $-4.3522 * * *$ & 1.7793 & 1.5981 \\
\hline GDP & 0.0017 & 0.5734 & -0.0440 & -1.6537 \\
\hline Export & -0.1385 & $-2.1638^{* *}$ & 1.6828 & 2.9503 \\
\hline
\end{tabular}

Note: Selected by the Schwarz Information Criterion (SC)

*** Significant at 0.01

** Significant at 0.05

* Significant at 0.1

In table 5, there were 1 unidirectional causality. Export was robustly affected by GDP in the short run. The directional from GDP to Export as found in some results of Rifat Barış Tekin (2012).

The increasing of output in Laos probably created input supply for industry in Thailand and directional the demand for input from Laos to Thailand as long run explained.

Table 4 Granger Causality Results

\begin{tabular}{cccc}
\hline \multirow{2}{*}{$\begin{array}{c}\text { Dependent } \\
\text { variable }\end{array}$} & FDI & Independent Variables & Export \\
\cline { 2 - 4 } & - & GDP & 1.7148 \\
\hline FDI & $6.3771^{*}$ & 2.3447 & 5.2517 \\
\hline GDP & $6.3316^{*}$ & $17.3261^{* * *}$ & -
\end{tabular}

Note: Selected by Schwarz Information Criterion (SC)

*** Significant at 0.01

** Significant at 0.05

* Significant at 0.1

\section{Conclusion}

The results show that there are long run relationships from Laos's GDP and Laos's exports to Thailand and from Thailand's direct investment and Laos's GDP to Laos's exports to Thailand. There is only one direction in short run from Laos's GDP to Laos's export to Thailand. The estimation results also indicate that only Laos's exporters received benefit from Thailand investment and economic growth in the short run. Lao's government should implement intensive action to be more attractive and encourage more foreign direct investment to be able to distribute income not only to the exports but also to boost the long run sustainable economic growth. Consequently, the acceleration of exports lead to larger scale of production and employment. This suggested policy implementation contributes to explaining the many advantages of Laos such as skilled labour, low wages and an abundance of natural resources. Nevertheless, the transportation and logistic costs remain high compared to other countries in the greater Mekong sub-region (GMS). 
Wattanakul \& Watchalaanun| The Relationship between Investment from Thailand and the Economic Growth of Laos

\section{References}

Asiedu, E. (2002). On the Determinants of Foreign Direct Investment to Developing Countries: Is Africa Different?, World Development, 30, 1, 107-19. https://doi.org/10.1016/S0305-750X(01)00100-0

Balasubramanyam, Venkataraman N., Salisu, Mohammed A., Sapsford, David. (1996). Foreign Direct Investment and Growth in EP and IS Countries. Economic Journal. 106: 92-105. https://doi.org/10.2307/2234933

Bank of Thailand. (2016). Trade Classified by Country (US\$). (Online) Retrieve October 20, 2559

http://www2.bot.or.th/statistics/BOTWEBSTAT.aspx?reportID $=744$ \&language=ENG

Bank of Thailand. (2016). Thai Direct Investment Abroad (Outflow) Classified by Country and Business Sector of Thai Investors (US\$). (Online) Retrieve October 20, 2559 from http://www2.bot.or.th/statistics/BOTWEBSTAT.aspx?reportID=848\&language=ENG

Borensztein, E., De Gregorio, J. and J. W. Lee (1998), "How Does Foreign Direct Investment Affect Economic Growth?," Journal of International Economics, vol. 45(1), pp. 115-135. https://doi.org/10.1016/S0022-1996(97)00033-0

Carkovic, M. and R. Levine. 2002. "Does Foreign Direct Investment Accelerate Economic Growth?" University of Minnesota, Working Paper.

Dunning. J.H. (2001). The Eclectic (OLI) Paradigm of International Production: Past, Present and Future. International Journal of the Economics of Business, 8(2): 173-90 https://doi.org/10.1080/13571510110051441

Engle, R. F. and C. W. J. Granger (1987). Co-integration and Error Correction: Representation, Estimation and Testing. Econometrica, 55, 251-276. https://doi.org/10.2307/1913236

Freeman, J.R. (1983). Granger Causality and the Time Series Analysis of Political Relationships. American Journal of Political Science, 27(2), pp.327-358. https://doi.org/10.2307/2111021

Gunawardana, P.J. (2008). Trends and Patterns of Foreign Direct Investment in Lao PDR. International Journal of Business and Management 3(1):41-57. doi: http://dx.doi.org/10.5539/ijbm.v3n1p41. https://doi.org/10.5539/ijbm.v3n1p41

Johansen, S., 1988, "Statistical Analysis of Co-integration Vectors," Journal of Economic Dynamics and Control, Vol. 12, No. 2-3, pp. 231-254. https://doi.org/10.1016/0165-1889(88)90041-3

Ministry of Planning and Investment. (2016). Statistics. Retrieve May 28, 2559 from http://www.investlaos.gov.la/index.php/resources/statistics.

Nelson, Charles R. and Heejoon Kang, (1981). Spurious periodicity in inappropriately detruded time series, Ecnometrica, 49, pp.741-751 https://doi.org/10.2307/1911520

Nick J. Freeman. (2002). "Foreign Direct Investment in Cambodia, Laos and Vietnam: A Regional Overview".16-17th August 2002. Paper prepared for the Conference on Foreign Direct Investment: Opportunities and Challenges for Cambodia, Laos and Vietnam. Hanoi.

Tekin R, B. (2012) Development aid, openness to trade and economic growth in Least

Developed Countries: bootstrap panel Granger causality analysis, Social and Behavioral Sciences 62 (2012) $716 \tilde{n} 721$

UNCTAD statistic. (2016). National accounts. (Online). Retrieve October 20, 2559 from http://unctadstat.unctad.org/wds/ReportFolders/reportFolders.aspx 


\section{Appendix 1}

Total Investment in Laos PDR sine 1989 to 2015

\begin{tabular}{|c|c|c|c|c|}
\hline No & Country & Unit & $\begin{array}{ll}\text { Value } & \text { of } \\
\text { Investment(US\$) }\end{array}$ & \%total value \\
\hline 1 & Lao & $2,561.00$ & $6,252,316,159.00$ & 25.54 \\
\hline 2 & China & 834.00 & $5,484,429,971.00$ & 22.41 \\
\hline 3 & Thailand & 748.00 & $4,491,684,613.00$ & 18.35 \\
\hline 4 & Vietnam & 417.00 & $3,574,681,539.00$ & 14.60 \\
\hline 5 & Korea, South & 291.00 & $751,072,139.00$ & 3.07 \\
\hline 6 & France & 223.00 & $490,626,243.00$ & 2.00 \\
\hline 7 & United States & 114.00 & $149,800,113.00$ & 0.61 \\
\hline 8 & Malaysia & 103.00 & $812,558,773.00$ & 3.32 \\
\hline 9 & Japan & 102.00 & $438,267,441.00$ & 1.79 \\
\hline 10 & Australia & 87.00 & $127,652,812.00$ & 0.52 \\
\hline 11 & Singapore & 79.00 & $187,761,475.00$ & 0.77 \\
\hline 12 & Taiwan & 73.00 & $86,663,554.00$ & 0.35 \\
\hline 13 & United Kingdom & 54.00 & $201,863,480.00$ & 0.82 \\
\hline 14 & Hong Kong & 49.00 & $83,547,259.00$ & 0.34 \\
\hline 15 & Canada & 40.00 & $65,791,144.00$ & 0.27 \\
\hline 16 & Germany & 31.00 & $7,833,128.00$ & 0.03 \\
\hline 17 & Russia & 24.00 & $38,459,130.00$ & 0.16 \\
\hline 18 & India & 22.00 & $163,772,237.00$ & 0.67 \\
\hline 19 & Netherlands & 16.00 & $434,466,484.00$ & 1.78 \\
\hline 20 & Sweden & 15.00 & $19,019,558.00$ & 0.08 \\
\hline 21 & Switzerland & 15.00 & $44,492,192.00$ & 0.18 \\
\hline 22 & Belgium & 13.00 & $3,694,852.00$ & 0.02 \\
\hline 23 & Cambodia & 11.00 & $8,363,324.00$ & 0.03 \\
\hline 24 & Italy & 9.00 & $4,478,813.00$ & 0.02 \\
\hline 25 & Denmark & 8.00 & $611,384.00$ & 0.00 \\
\hline 26 & Myanmar & 7.00 & $1,710,000.00$ & 0.01 \\
\hline 27 & Sri Lanka & 7.00 & $1,035,000.00$ & 0.00 \\
\hline 28 & Norway & 6.00 & $346,435,550.00$ & 1.42 \\
\hline 29 & New Zealand & 6.00 & $1,592,000.00$ & 0.01 \\
\hline 30 & Israel & 5.00 & $2,692,600.00$ & 0.01 \\
\hline 31 & Korea, North & 4.00 & $1,732,800.00$ & 0.01 \\
\hline 32 & Indonesia & 4.00 & $106,719,551.00$ & 0.44 \\
\hline 33 & Bangladesh & 3.00 & $250,000.00$ & 0.00 \\
\hline 34 & Philippines & 3.00 & $218,000.00$ & 0.00 \\
\hline 35 & Finland & 3.00 & $1,249,065.00$ & 0.01 \\
\hline 36 & Pakistan & 3.00 & $489,784.00$ & 0.00 \\
\hline
\end{tabular}


Wattanakul \& Watchalaanun| The Relationship between Investment from Thailand and the Economic Growth of Laos

\begin{tabular}{|c|c|c|c|c|}
\hline No & Country & Unit & $\begin{array}{l}\text { Value } \\
\text { Investment(US\$) }\end{array}$ & \%total value \\
\hline 37 & Nepal & 3.00 & $500,000.00$ & 0.00 \\
\hline 38 & Hungary & 3.00 & $380,000.00$ & 0.00 \\
\hline 39 & Spain & 2.00 & $202,800.00$ & 0.00 \\
\hline 40 & Iceland & 2.00 & $164,000.00$ & 0.00 \\
\hline 41 & Austria & 2.00 & $390,000.00$ & 0.00 \\
\hline 42 & Bolivia & 2.00 & $230,000.00$ & 0.00 \\
\hline 43 & Tajikistan & 1.00 & $1,000,000.00$ & 0.00 \\
\hline 44 & Ukraine & 1.00 & $200,000.00$ & 0.00 \\
\hline 45 & Angola & 1.00 & $37,500,000.00$ & 0.15 \\
\hline 46 & Bukina Faso & 1.00 & $1,530,000.00$ & 0.01 \\
\hline 47 & Panama & 1.00 & $1,750,000.00$ & 0.01 \\
\hline 48 & Peru & 1.00 & $3,000,000.00$ & 0.01 \\
\hline 49 & Cuba & 1.00 & $185,000.00$ & 0.00 \\
\hline 50 & Luxembourg & 1.00 & $200,000.00$ & 0.00 \\
\hline 51 & $\begin{array}{l}\text { International Finance } \\
\text { Corpor }\end{array}$ & 1.00 & $1,590,000.00$ & 0.01 \\
\hline 52 & Mali & 1.00 & $40,000,000.00$ & 0.16 \\
\hline \multirow[t]{2}{*}{53} & Turkey & 1.00 & $100,000.00$ & 0.00 \\
\hline & total & $6,015.00$ & $24,476,953,967.00$ & 100.00 \\
\hline
\end{tabular}

Source: Ministry of Planning and Investment, LOAS PDR (2016) 
AABFJ | Volume 11, no. 3, 2017

\section{Appendix 2}

Thailand direct investment to Laos and Laos' export to Thailand since 2005 to 2015

\begin{tabular}{|l|l|l|}
\hline Year & Thailand direct investment to Laos & Laos' export to Thailand \\
\hline 2005 & 13.7 & 224.36 \\
\hline 2006 & 25.58 & 515.78 \\
\hline 2007 & 83.54 & 470.06 \\
\hline 2008 & 214.35 & 616.85 \\
\hline 2009 & 461.33 & 462.73 \\
\hline 2010 & 566.71 & 749.38 \\
\hline 2011 & 725.18 & $1,130.37$ \\
\hline 2012 & 1082.52 & $1,238.29$ \\
\hline 2013 & 1414.9 & $1,360.05$ \\
\hline 2014 & 1350.01 & $1,410.56$ \\
\hline 2015 & 1597.34 & $1,471.43$ \\
\hline
\end{tabular}

Source: Bank of Thailand (2016)

Note: Thailand's direct investment to Laos was FDI outflows to Laos or Lao FDI inflows from Thailand and Laos' export to Thailand are Thailand's imports from Laos. 